\title{
Serious Game Conceptual Model of Brain-Based Learning for Halus Student
}

\author{
Saffa Raihan Zainal Abidin, Siti Fadzilah Mat Noor* and Noraidah Sahari@ \\ Ashaari
}

Faculty of Information Science \& Technology, Universiti Kebangsaan Malaysia, 43600 UKM, Bangi, Selangor, Malaysia

\begin{abstract}
Malaysian society, including students who use technology in their daily lives, have made technology a necessity. Among the media technologies that have a place in students' hearts are serious games, convey information, emphasizing learning and not entertainment. A serious game is capable of creating self-directed active learning. In this study, the authors analyzed the key features of serious games that encourage learning in an academic environment. However, not many software specializes in problems for slow-reading students. This study aims to establish the elements used in in-game application software and the approaches and strategies used to develop a serious game design conceptual model for such students based on the acquired elements. The elements were obtained through two methods, i.e., systematic literature review and preliminary studies. This work identifies 48 potential studies in 2009-2020, using various well-known digital libraries. The analysis of the selected documents applying the inclusion criteria resulted in 12 articles used to design serious games. This study

ARTICLE INFO

Article history:

Received: 19 June 2021

Accepted: 24 August 2021

Published: 28 October 2021

DOI: https://doi.org/10.47836/pjst.29.4.49

E-mail addresses:

saffaraihan@siswa.ukm.edu.my (Saffa Raihan Zainal Abidin)

fadzilah@ukm.edu.my (Siti Fadzilah Mat Noor)

nsa@ukm.edu.my (Noraidah Sahari@Ashaari)

*Corresponding author integrates brain-based learning strategies into game and learning components. This serious game conceptual model expects to provide a meaningful learning experience for those children who are left behind to achieve their learning goals and increase their motivation to stay excited in learning. Keywords: Brain-based learning, serious game, slow reader student
\end{abstract}

ISSN: 0128-7680

e-ISSN: 2231-8526 


\section{INTRODUCTION}

The technological integrations that have gotten teachers and students are serious games readily available at affordable prices. In a survey of online gaming by Rakuten Insight in March 2020, 73 percent of Malaysian respondents aged between 16 and 24 stated that they played online games (Hirschmann, 2020). The same survey found that a large portion of Malaysian gamers played games daily. Students born in the next generation or Gen Z (born between 1998 and the present) are modern students who grew up in digital times. However, the game to consider is that involving pedagogy, which is a serious game. Abidin et al. (2019) state that a serious game can refer to the game's purpose in imparting a message, whether in education or training. Serious games can help students learn flexibly regardless of time and place and reduce dependency on teachers. According to Auzar (2012), the process of T\&L through a serious game is active learning because it promotes the active involvement of students through two-way interaction with software without relying entirely on teachers.

Abidin et al. (2019) state that designing games for children are challenging because they differ from adults in characteristics, and it is essential to understand their needs. Much software in the market are designed specifically for students with learning problems, and the rest are for children with normal learning abilities. These children need more consideration and the intervention of technology and aiding tools to enhance their learning to be equivalent to other normal children (Stanberry \& Raskind, 2019). Past studies show that much software in the market proposes different design techniques and methods to help children with learning difficulties, especially reading literacy. Literacy was defined as the ability to read, write and use, simple and complex sentences and apply that knowledge in daily learning and communication (KPM, 2015). In this study, slow learner refers to students with low cognitive ability but not in the special needs' category called Halus students. In addition to the contents, the strategies used are also important to ensure the software's success. A strategy is an organized plan to achieve goals or success. In this serious game, the Brain-Based Learning (BBL) strategy is an appropriate strategy to be applied in the teaching medium to help students optimize their brain usage and enhance student attention in learning.

The use of BBL strategies can optimize the use of the left and right brain and activate the neuron cells of the user's brain. Halus students can have the same level of thinking as regular students if the strategies and methods used can stimulate their brains. This strategy applied to Halus students aims to achieve the three lowest levels in the low and medium levels of thinking of Anderson's Taxonomy, namely application, understanding and remembering. Past studies have found that conventional learning is considered more attractive if it incorporates appropriate technological elements. However, most of these serious games are not designed and tailored to users' needs ( $\mathrm{Ng}$ et al., 2015), especially 
for a slow learner. Serious games that have been used also do not have elements suitable for Halus students, such as less attractive, boring storylines and unattractive graphics. If the software is not optimized for its learning usage, it is deemed ineffective even though the content is excellent and appropriate. This strategy is chosen because the colour, shape, texture, sound, gameplay elements, and pedagogy can stimulate the entire left and right brain. The development of brain studies has introduced 12 principles of BBL via three instructional techniques associated with these principles (Caine \& Caine, 1991). The BBL strategy Hileman (2006), which is B.R.A.I.N.B.A.S.E.D, into serious games, is seen to be helping students keep their attention in learning and improving their motivation. To outline this paper, we start with an introduction, background literature, methodology, model design, discussion and conclusion.

\section{BACKGROUND LITERATURE}

This section discusses the literature studies related to students left behind in learning or low cognitive students known as Halus students, serious game technology used, and brainbased learning (BBL) approach.

\section{Halus Students (Slow Reading Students)}

Reading is an essential skill, which helps students succeeding in their learning. Mastery in reading skills dramatically impacts students' daily performance, including examinations (Jamian, 2011). Conversely, students who are not interested and weak in learning are because of their incompetence in mastering reading and writing skills (Jamian, 2011). Thus, Halus students are one of the most challenging learning issues to overcome. In this study, Halus focuses on children who are not in the special learning category but the regular student category. Their cognitive ability might be slightly different from normal students, and they struggle to meet academic demands (Abidin et al., 2017). According to Chauhan (2011), Halus students need help to expedite their learning because they have limited capabilities involving symbols and abstracts such as languages, numbers and concepts.

\section{Serious Game}

The serious game has proven to motivate students and improve their learning performance effectively and interestingly (Masrop et al., 2015). Students prefer something enjoyable while learning, allowing them to play simultaneously (Su et al., 2016). Any game designed solely for consumer entertainment is not a serious game (Møller \& Hansen, 2016). Serious games show great potential in stimulating the cognitive abilities of all ages, including children (Zaki et al., 2015).

However, a serious game designed has to have fine-tuned pedagogy (Bellotti et al., 2010). Among the critical issues in the game involving pedagogy is an insufficient 
combination of educational and game design principles. The game mechanics that are not appropriate for certain target users causes the game's objective to fail. Besides, the use of games is proven to increase motivation, but students are likely to be passive in-class activities and performed badly on writing assignments (Domínguez et al., 2013). Thus, game elements have different positive effects on a gameplay concept, and the effectiveness of each of these elements needs to be reviewed to suit the user for a positive impact.

Many previous studies have discussed the positive aspects of using digital game software in learning which is: i) Improve cognitive and motor skills and help improve ICT skills (Peirce, 2013), ii) Learning is more effective (Martin \& Shen, 2014); iii) Increase the focus of attention among students with short-term convergence problems (Boyler, 2010) and exacta.

\section{Brain-based Learning}

In addition to games and pedagogy for Halus students, the approaches used need to be considered when designing the game model in-game designs. Thus, the BBL approach is a good technique that motivates teachers to plan a teaching strategy to boost motivation and student performance.

As long as the brain is not restricted from fulfilling the normal processes, learning will take effect. BBL approach is based on the structure and function of the brain. BBLs can be applied in the T\&L process by considering Halus student's needs and learning styles to assess and improve gaming software's delivery content (Binulal \& Aravind, 2013). BBLs involve knowledge and teaching about the function and regulation of the brain for meaningful learning. Generally, all learning is brain-based, but BBL is a technique that considers the brain's optimal function compared to the traditional method (Caine \& Caine, 1991). Optimal brain usage uses the entire brain by involving as many senses as possible simultaneously. In this BBL, students are fully engaged, in which the learning patterns are changed from relaxed to active learning patterns so that every part of the brain can play an optimal role (Mandar, 2011).

Caine and Caine (1991) have also issued 12 BBL principles to determine and select appropriate strategies and methodologies. According to Fazil and Saleh (2016), understanding the student's concept on the topic is emphasized based on a brain-based teaching strategy. Expose students to seven phases of BBL: activation, explaining the learning outcomes and learning process involved, creating relevance, carry out learning activities, demonstrating student understanding, reassess students' memory/make a conclusion, and preview new topics that have made them more focused and also give them more opportunities to engage throughout the learning process actively. This exposure has directly contributed to the optimum conditions for students learning. 
Fazil and Saleh (2016) state, the BBL approach highlights the relevance between new information and students' prior knowledge to make students more aware of the T\&L process. Through gameplay, inputs are given in various visual, audio and kinaesthetic forms to allow students to create relevance between the information obtained to build the desired meaning. This BBL can improve the comprehension and achievement of students in learning (Bawaneh et al., 2012). Based on Saleh and Halim (2016), BBL that focuses on overall brain function can self-potential and student achievement when brain function is used optimally with the help of the teacher's teaching method.

Based on BBL, can use principle strategies in T\&L to encourage student engagement in the classroom and increase their motivation. According to Hileman (2006), if students are not motivated, they would not want to learn voluntarily, and meaningful learning will not happen. Meaning is when can link new knowledge to previous knowledge. This is supported by the study of Bawaneh et al. (2010) and She (2012), stating the meaningful learning can make learning more effective and be remembered longer. Furthermore, a study by Bawaneh et al. (2010) and She (2012) stated that the BBL method could speed up thinking, planning and execution processes that enhance the conceptual understanding and motivations to continue learning. Therefore, integrating the BBL strategy in a serious game is expected to improve Halus students' literacy skills by maintaining their attention and boosting their motivation to continue learning.

\section{METHODOLOGY}

This study used two methods; i) Systematic Literature Review (SLR), which is adapted from $\mathrm{Ng}$ et al. (2015), and ii) Preliminary studies to strengthen the findings of the study that involving questionnaires and observation that are conducted at two schools.

This study performed a targeted search of relevant studies to answer the research questions. Articles related to relevant elements in games, pedagogy and practical brainbased learning to build a model for the slow learner in literacy are gathered and studied extensively. The proposed SLR method has four phases. First, this method is intended to view existing studies specifically for slow reader children in Malaysia and looking for suitable components and elements in model design. After identifying the appropriate element, a preliminary study was conducted to strengthen the literature's initial findings.

A preliminary study has four phases comprising a questionnaire and observation: Phase 1 identifies the purpose of the study. Phase 2 examines past studies to find support and build a questionnaire instrument through journal readings. Phase 3 is the method used in the preliminary study (questionnaire with teachers and class observation). .Finally, Phase 4 analyzes data to form a serious game model. 


\section{Systematic Literature Review}

Four steps in the systematic literature review are discussed.

Identifying and Downloading Related Articles. The objective of the literature review was identified so that the related articles downloaded are a match. The selection of articles uses two methods. The first method, an initial selection, screened selected the articles from years 2009-2020. Then, implemented the search strategy based on four aspects: (a) serious games, (b) computer application, (c) educational games, (d) and (d) computer games relating to ("design" OR "methodology" OR "frameworks" OR "model”). To refine the selection of the works, applied the inclusion and exclusion criteria, a general review of each article's title and abstract and conclusions are considered (Table 1).

Table 1

Selection Criteria

\begin{tabular}{ll}
\hline Selection Criteria & Exclusion Criteria \\
$\begin{array}{l}\text { Papers that detail methodologies, models, } \\
\text { frameworks and design of serious games. } \\
\begin{array}{l}\text { Approaches that detail phases, stages or } \\
\text { processes of development of serious games. }\end{array}\end{array}$ & $\begin{array}{l}\text { Articles published on the company and } \\
\text { websites. }\end{array}$ \\
$\begin{array}{l}\text { Articles that mention serious game design but } \\
\text { do not define their details of the development. } \\
\text { Computer applications such as simulation, } \\
\text { voice recognition and augmented. }\end{array}$ \\
$\begin{array}{l}\text { Articles relevant to the research questions. } \\
\text { Focusing on the researcher in Malaysia } \\
\text { especially, in Malay }\end{array}$ & Foreign Language
\end{tabular}

Electronic databases were used, including areas associated with education and Computing, Engineering and Technology, and Psychology. They were identified as sources of information: journals, conferences, and proceedings. The databases reviewed were: Science Direct Elsevier, IEEE eXplorer Digital Library, Springer, ACM Digital Library, Taylor \& Francis, Proquest, and Google Scholar used for downloading articles. The downloaded articles were then managed and organized using the Mendeley program to more manageable references. Selected papers were written in Malay and English and focused only on researches in Malaysia. According to Bandara et al. (2011), the method used is the 'primary' articles focusing specifically on the title.

The second method, known as 'secondary' source as the search needed to be wider rather than look at the title. Usually, the article title does not mention the domain, but the contents are related. The search was done quickly, reading abstract and content before focusing on the critical content. Table 2 shows the downloaded articles; twelve studies belonging to a learning software application for slow-reading children, including specific 
learning problems, have been identified. All downloaded software was specific for the Malay language because it conformed to Malaysia's students' patterns and cultures.

Analyzing Related Articles. The analysis started to look at the criteria and specifications of the articles. Target users were focused on children with difficulty in language literacy, either normal children or those with learning problems such as Down syndrome and dyslexia, to see additional elements or approaches used to suit the user. Bandara et al. (2011) state, the critical aspects observed during the analysis of literature studies include definitions, objectives, characteristics, historical analysis, success factors, failure/problem factors, research methods, theory, further studies, and contents.

Evaluating the Quality of A Study. For example, a study that was not documented in detail was not chosen, and the articles selected are from a reliable database to ensure the quality of a study. The chosen articles then were analyzed during the preliminary study.

Making Conclusions and Discussions. The elements obtained are listed in Table 2. In addition, Table 2 shows previous studies in developing technology for computer application, specifically in the mastery of reading skills for children with learning disabilities.

The researcher categorized the serious game component into three main parts from Table 2: game, learning, and BBL strategy. The selected game components consist of game objectives, storyline, avatars, emotions, feedback, interactivity, rules and challenges. The learning component consists of learning objectives, theory, content design, content structure design, serious game technology, teaching media, and BBL strategies. The BRAINBASED strategy by Hileman (2006) is applied into the serious game for the BBL strategy. All of these components will then be seen to suit the Halus students in the preliminary study conducted.

Table 2

Literature review of computer application in literacy for Halus students

\begin{tabular}{|c|c|c|c|}
\hline Authors & $\begin{array}{l}\text { Software Name/ } \\
\text { Details }\end{array}$ & Details & Elements \\
\hline $\begin{array}{l}\text { Azid et al. } \\
(2020)\end{array}$ & $\begin{array}{l}\text { Evaluating User } \\
\text { Experience of } \\
\text { Using Cerdik } \\
\text { BM Series } 1 \\
\text { Interactive } \\
\text { Pedagogical } \\
\text { Tool }\end{array}$ & $\begin{array}{l}\text { 1. The results conclude that Cerdik } \\
\text { BM's development based on the 4-D } \\
\text { development study process enabled } \\
\text { researchers to develop an interactive } \\
\text { pedagogical tool that could stimulate } \\
\text { students' thinking abilities, language } \\
\text { skills, motivation and trust in the } \\
\text { LINUS programmed. }\end{array}$ & $\begin{array}{ll}\text { 1. } & \text { Multiple } \\
\text { 2. } & \text { Verbal } \\
\text { 2. } & \text { Linguistics } \\
\text { 3. } & \text { Mathematical } \\
& \text { Logic } \\
\text { 4. Kinesthetic } \\
\text { 5. } \\
\text { 6. } \\
\text { 7. Interpersonal } \\
\text { 8. } & \text { Naturapersonal } \\
\end{array}$ \\
\hline
\end{tabular}


Table 2 (Continued)

\begin{tabular}{|c|c|c|c|}
\hline Authors & $\begin{array}{l}\text { Software } \\
\text { Name/ } \\
\text { Details }\end{array}$ & Details & Elements \\
\hline $\begin{array}{l}\text { Ahmad et al. } \\
(2017)\end{array}$ & $\begin{array}{l}\text { Voice } \\
\text { Recognition } \\
\text { to overcome } \\
\text { reading } \\
\text { difficulties }\end{array}$ & $\begin{array}{l}\text { 1. This article suggested a } \\
\text { process diagram that uses data } \\
\text { from a learning portfolio and } \\
\text { simultaneously considers the } \\
\text { degree of difficulty in relational } \\
\text { reading during the diagnostic test. }\end{array}$ & $\begin{array}{l}\text { 1. Voice } \\
\text { recognition }\end{array}$ \\
\hline $\begin{array}{l}\text { Miswan and } \\
\text { Adnan (2015) }\end{array}$ & $\begin{array}{l}\text { Pembangunan } \\
\text { Aplikasi } \\
\text { Peranti Mudah } \\
\text { Alih untuk } \\
\text { Kemahiran } \\
\text { Membaca } \\
\text { Kanak-Kanak: } \\
\text { Aplikasi } \\
\text { Literasi } \\
\text { LINUS } \\
\text { (LiLIN) }\end{array}$ & $\begin{array}{l}\text { 1. The core features of the LiLIN } \\
\text { framework include learning } \\
\text { syllables and word spelling in } \\
\text { immersive digital and multi-touch } \\
\text { ways-responding to correct or } \\
\text { incorrect answers automatically, } \\
\text { incorporating audio spelling for } \\
\text { alphabets and syllables, spelling } \\
\text { and writing activities, and the } \\
\text { engaged and collaborative } \\
\text { learning game-like approach. }\end{array}$ & $\begin{array}{l}\text { 1. Pedagogy } \\
\text {-Repetition } \\
\text {-Conceptualization } \\
\text {-Themed presentation } \\
\text {-Coaching training } \\
\text {-Closing } \\
\text { 2. Content } \\
\text {-LINUS teaching } \\
\text { module unit } 1 \text { and } 2 \\
\text { 3. Technology } \\
\text {-IOS system } \\
\text {-Multi-touch } \\
\text {-Multimedia } \\
\text {-Interactive }\end{array}$ \\
\hline $\begin{array}{l}\text { Ng et al. } \\
(2016)\end{array}$ & $\begin{array}{l}\text { Perisian } \\
\text { Pembelajaran } \\
\text { bagi bahasa } \\
\text { Melayu }\end{array}$ & $\begin{array}{l}\text { 1. The purpose of the study is to see } \\
\text { the effectiveness of persuasive } \\
\text { designs implemented in software } \\
\text { for children with learning } \\
\text { disabilities focused on the subject } \\
\text { of Bahasa Melayu. }\end{array}$ & 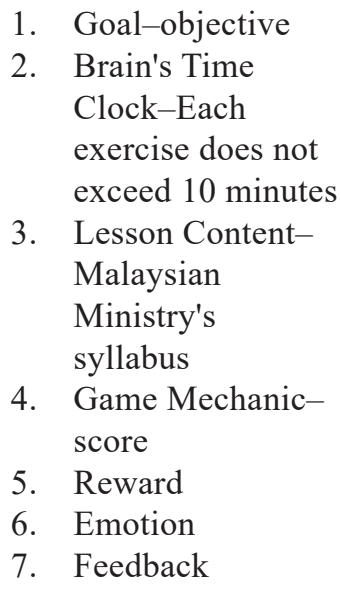 \\
\hline
\end{tabular}


Table 2 (Continued)

\begin{tabular}{|c|c|c|c|}
\hline Authors & $\begin{array}{l}\text { Software } \\
\text { Name/ Details }\end{array}$ & Details & Elements \\
\hline $\begin{array}{l}\text { Sidek et al. } \\
(2014)\end{array}$ & $\begin{array}{l}\text { Perisian 'Saya } \\
\text { Suka Belajar' }\end{array}$ & $\begin{array}{l}\text { 1. The software's objective } \\
\text { is to enable students to } \\
\text { build and read open/ closed } \\
\text { syllabus, build words out } \\
\text { of letters/syllables, select, } \\
\text { match and copy syllables } \\
\text { into meaningful words, } \\
\text { read words constructed } \\
\text { from syllables, spell and } \\
\text { sound, and write simple } \\
\text { syllables. }\end{array}$ & $\begin{array}{l}\text { 1.Text-minimal, } \\
\text { understandable, simple and } \\
\text { in the form of instructions } \\
\text { 2.Graphic (image)- } \\
\text { Caricature image, colourful, } \\
\text { attractive graphic with } \\
\text { colours usage. } \\
\text { 3.Animation-attract students } \\
\text { to focus } \\
\text { 4.Navigation-consistent, } \\
\text { simple and easy. } \\
\text { 5.User Friendly-exciting } \\
\text { and cheerful. } \\
\text { 6.Focus- Content of the } \\
\text { lesson related to everyday } \\
\text { life. }\end{array}$ \\
\hline $\begin{array}{l}\text { Ahmad } \\
\text { et al. } \\
(2013)\end{array}$ & MyLINUS & $\begin{array}{l}\text { 1. Develop software for } \\
\text { students under the LINUS } \\
\text { program to overcome the } \\
\text { difficulty of reading. }\end{array}$ & $\begin{array}{l}\text { 1. Goal-objective } \\
\text { 2.Content-curriculum } \\
\text { 3. Repetition } \\
\text { 4. Colourful image } \\
\text { 5. Recall } \\
\text { 6.Storyline } \\
\text { 7.Rule } \\
\text { 8.Challenge } \\
\text { 9.Active learning }\end{array}$ \\
\hline $\begin{array}{l}\text { Ramli and } \\
\text { Zaman } \\
(2011)\end{array}$ & $\begin{array}{l}\text { Perisian AR } \\
\text { BACA SindD }\end{array}$ & $\begin{array}{l}\text { 1. Multimedia software } \\
\text { is explicitly designed } \\
\text { for children with Down } \\
\text { syndrome. } \\
\text { 2. The Augmented Reality } \\
\text { (AR) technique has been } \\
\text { used in this software. }\end{array}$ & $\begin{array}{l}\text { Goal-objective } \\
\text { Immersive } \\
\text { Feedback }\end{array}$ \\
\hline $\begin{array}{l}\text { Yussof } \\
\text { and } \\
\text { Shima } \\
(2012)\end{array}$ & MEL-SindD & $\begin{array}{l}\text { 1. Develop software for Down } \\
\text { Syndrome children to learn } \\
\text { Malay. This software applies } \\
\text { scaffolding and multimedia } \\
\text { techniques. }\end{array}$ & $\begin{array}{l}\text { 1. Goal- Objective } \\
\text { 2. Game mechanic } \\
\text { 3. Motivation } \\
\text { 4. Emotion } \\
\text { 5. Active learning } \\
\text { 7. Multimedia elements } \\
\text { 8. Feedback }\end{array}$ \\
\hline
\end{tabular}


Table 2 (Continued)

\begin{tabular}{|c|c|c|c|}
\hline Authors & $\begin{array}{l}\text { Software Name/ } \\
\text { Details }\end{array}$ & Details & Elements \\
\hline $\begin{array}{l}\text { Amian } \\
(2012)\end{array}$ & $\begin{array}{l}\text { Multimedia } \\
\text { Interaktif }\end{array}$ & $\begin{array}{l}\text { 1. Findings show that interactive } \\
\text { multimedia improves reading skills' } \\
\text { performance helps create an active } \\
\text { learning environment, and is an effective } \\
\text { teaching aid for teachers and students. }\end{array}$ & $\begin{array}{l}\text { Combines various } \\
\text { multimedia } \\
\text { elements }\end{array}$ \\
\hline $\begin{array}{l}\text { Othman } \\
\text { and } \\
\text { Pakar } \\
(2011)\end{array}$ & $\begin{array}{l}\text { Interactive } \\
\text { Storytelling } \\
\text { Software } \\
\text { Application }\end{array}$ & $\begin{array}{l}\text { 1. The t-test analysis findings show } \\
\text { a significant difference in reading } \\
\text { comprehension performance between } \\
\text { middle-achieving students who follow the } \\
\text { reading comprehension using computer } \\
\text { applications interactively with medium- } \\
\text { achieving students who follow the } \\
\text { teaching using traditional methods in } \\
\text { post-test. }\end{array}$ & $\begin{array}{l}\text { 1. Interactive } \\
\text { 2. Colourful }\end{array}$ \\
\hline $\begin{array}{l}\text { Mahidin et } \\
\text { al. (2011) }\end{array}$ & E-Z Disleksia & $\begin{array}{l}\text { 1. This software is devoted to Dyslexia } \\
\text { children who have difficulty reading and } \\
\text { learning Malay. }\end{array}$ & $\begin{array}{l}\text { Goal-Objective } \\
\text { Content-pedagogy } \\
\text { and curriculum } \\
\text { Interactive } \\
\text { Colours- }\end{array}$ \\
\hline
\end{tabular}

\section{Preliminary Study}

A preliminary study involving questionnaire and observation methods was used to validate the elements obtained in the literature review and find suitable elements that suit Halus students. This preliminary study involved 4 phases.

Phase 1. The researcher identifies the preliminary study's objective by looking at the problems of conventional methods by teachers, game elements, pedagogy and brain-based learning appropriate for the serious game model based on literature.

Phase 2. Find support evidence for the findings by review related to previous studies. From the readings, one questionnaire instrument was produced by adaptions from several related journals.

Phase 3. Observations of LINUS and Pemulihan students and questionnaire methods with the teachers were done to collect the data.

Observation: The method was carried in two different schools and was made in classrooms to see and understand the T\&L process conditions for Halus students. Driscoll (2011) states that two common ways to observe people are participant observation and unobtrusive observation. For this study, the researcher chooses unobtrusive observation. The researcher 
does not interact with participants but rather record their behavior. Due to the Halus students inability to read and understand the questions well, this method is seen as the best method. Once the primary research data has been collected, the researcher will analyze the results.

The purpose of analyzing data is to look at what had been collected and create a cohesive, systematic interpretation to examine the validity of the elements. The observations were recorded in the form of a double-entry notebook and visual recording in the class. Before the class session started, the researcher wrote thick descriptions of what will observe, including descriptions of the scene, student's behaviors, and overall conclusions about students in the class session.

Questionnaire: A questionnaire is a research instrument consisting of questions or other prompts aiming to collect information from a respondent. The researcher used a questionnaire of close-ended questions, and the data collected from a data collection questionnaire is quantitative. The questionnaire aims to look at existing problems and the need to use serious games in learning. The respondents consisted of 11 teachers involved in the subjects of Bahasa, LINUS and Recovery program in two schools, that 7 of the Sekolah Rendah Kebangsaan Proton City and 4 teachers of Sekolah Rendah Jenis Kebangsaan (Tamil) Ladang Kalumpang.

Phase 4. The results of the questionnaire, among the problems faced by students with a mean exceeding 3.40, which is the high category is High level of dependence on teachers $($ mean $=4.55)$, Repetition of the learning process frequently occurs (mean $=5.00)$, and Teaching Aids can attract students to learn $($ mean $=4.91)$. The questionnaire results proved the conventional method of Halus students who need teaching aids such as serious games.

The results obtained from the observation are listed in Table 3. The purpose of this observation is to strengthen the researcher's findings in the literature review and explore the ideas and feelings of the respondents. The appropriate elements of the study are selected and formed into a serious game model for Halus students.

Table 3

The results of the preliminary study-Observation

\begin{tabular}{lll}
\hline & $\begin{array}{l}\text { Sekolah Kebangsaan Proton } \\
\text { City, Tanjong Malim, Perak }\end{array}$ & $\begin{array}{l}\text { Sekolah Jenis Kebangsaan Tamil } \\
\text { Ladang Kalumpang, Hulu Bernam, } \\
\text { Selangor }\end{array}$ \\
\hline $\begin{array}{l}\text { Number of } \\
\begin{array}{l}\text { Halus } \\
\text { students } \\
\text { observed }\end{array}\end{array}$ & Six students & Nine students \\
\hline
\end{tabular}




\begin{tabular}{|c|c|c|}
\hline & \multicolumn{2}{|r|}{ School } \\
\hline & $\begin{array}{l}\text { Sekolah Kebangsaan Proton } \\
\text { City, Tanjong Malim, Perak }\end{array}$ & $\begin{array}{l}\text { Sekolah Jenis Kebangsaan Tamil Ladang } \\
\text { Kalumpang, Hulu Bernam, Selangor }\end{array}$ \\
\hline $\begin{array}{l}\text { Duration of } \\
\text { Observation }\end{array}$ & $20-25$ minutes & $15-20$ minutes \\
\hline Elements & $\begin{array}{l}\text { 1. Create an active learning } \\
\text { environment } \\
\text { 2. Like colorful images } \\
\text { 3. Limiting the time for a } \\
\text { period of activity }\end{array}$ & $\begin{array}{l}\text { 1. Create an active learning environment } \\
\text { 2. Like colorful images } \\
\text { 3. Attracted to something new } \\
\text { 4. Attracted to audio and music }\end{array}$ \\
\hline
\end{tabular}

This Prototype Conceptual Model was developed to ensure that the serious game applications developed meet the specifications of the needs of Halus students and become an effective aid tool for them. The design of the Prototype Conceptual Model is an adaptation of the elements and components of the model that contains a solid pedagogical foundation and game elements appropriate to the Halus students. This model is classified into two core elements, namely learning and game. Both elements match Anderson's ordered Thinking Skills, i.e. apply, understanding and retention. In addition, the BBL approach is also adapted and applied to give an adequate impression in helping the Halus students.

\section{Elements of the Model}

Kapp (2012) lists game elements commonly used: players, abstractions, rules, feedback, quantifying results, emotional results, and storytelling. The combination of game elements can make the difference in determining the success or failure of the game and enhancing motivation and interest in learning. Based on SLR and preliminary study, the elements corresponding to Halus students can be divided into core element learning mechanics and game mechanics. Therefore, this element is classified into core elements. Through literary reading and endorsed by preliminary study, it has proven that this element positively impacts maintaining a concentration, understanding and further enhancing student's interest in learning. The next subtopic will parse the selected element based on the shortlist in Table 4.

\section{Design of the Model}

Education is one of the critical aspects of human life. The BBL approach in learning is to optimize the brain's use and be aligned with how the brain works to learn. The assumption is that a human brain is highly potential, and every student can learn effectively if their 
brains are allowed to function and play an optimal role (Jensen, 2008). The strategies applied in this gaming software are expected to help students in reading skills. In addition, the use of software facilitates the learning process by providing creative and innovative methods in teaching students with special needs rather than conventional methods (Suratin \& Mahadi, 2016).

Figure 1 shows a proposed serious game model for Halus students that applies the BBL strategy (Hileman, 2006). The elements of the model are based on findings in SLR and preliminary studies. Based on Shapi'i and Ghulam (2016), designing a framework or model is to identify the core elements and pattern that make the game a success, where the fundamental objective is learning while enjoying the fun of playing. This model has two main plan, which is education and serious game. The education plan uses learning mechanics while serious games use game mechanics to acquire outcomes, skills and motivation. Those mechanics are assisted by the BBL approach (Hileman, 2006). Those strategies are applied in both teaching and serious game. Zhonggen (2019) states, learning and gaming attributes are interlinked and an important influencing factor in T\&L in improving learning effectiveness and enhancing the learning experience in T\&L in improving learning effectiveness and enhancing the learning experience.

\section{Education and Serious Game}

Two central part of this model is education and a serious game plan. A serious game is a classification of digital games designed with a main pedagogical goal for education and training. The serious game plan has the goal of the most serious game, making players learn higher-order thinking skills. Both education and serious game plan have been classified in Table 4 based on Bloom's ordered Thinking Skills.

Figure 2 shows Anderson's Taxonomy started by Anderson and Krathwohl (2001), adapted Bloom's idea, but few changes were made where replaced replaced 'knowledge' s replaced with 'remember'. In comparison, the higher-order levels of 'evaluation' and 'synthesis' we the place so that 'creating' or 'synthesis' were reflected as the highest order of thinking. This taxonomy evaluates the level of intelligence that people use to attain knowledge. It shows the different states of behavior that are required to learn information. For post-primary education, of the goals to achieve is critical or higher-order thinking skills. However, to reach that top level of thinking skills, one must first attain the lower order of thinking skills. 


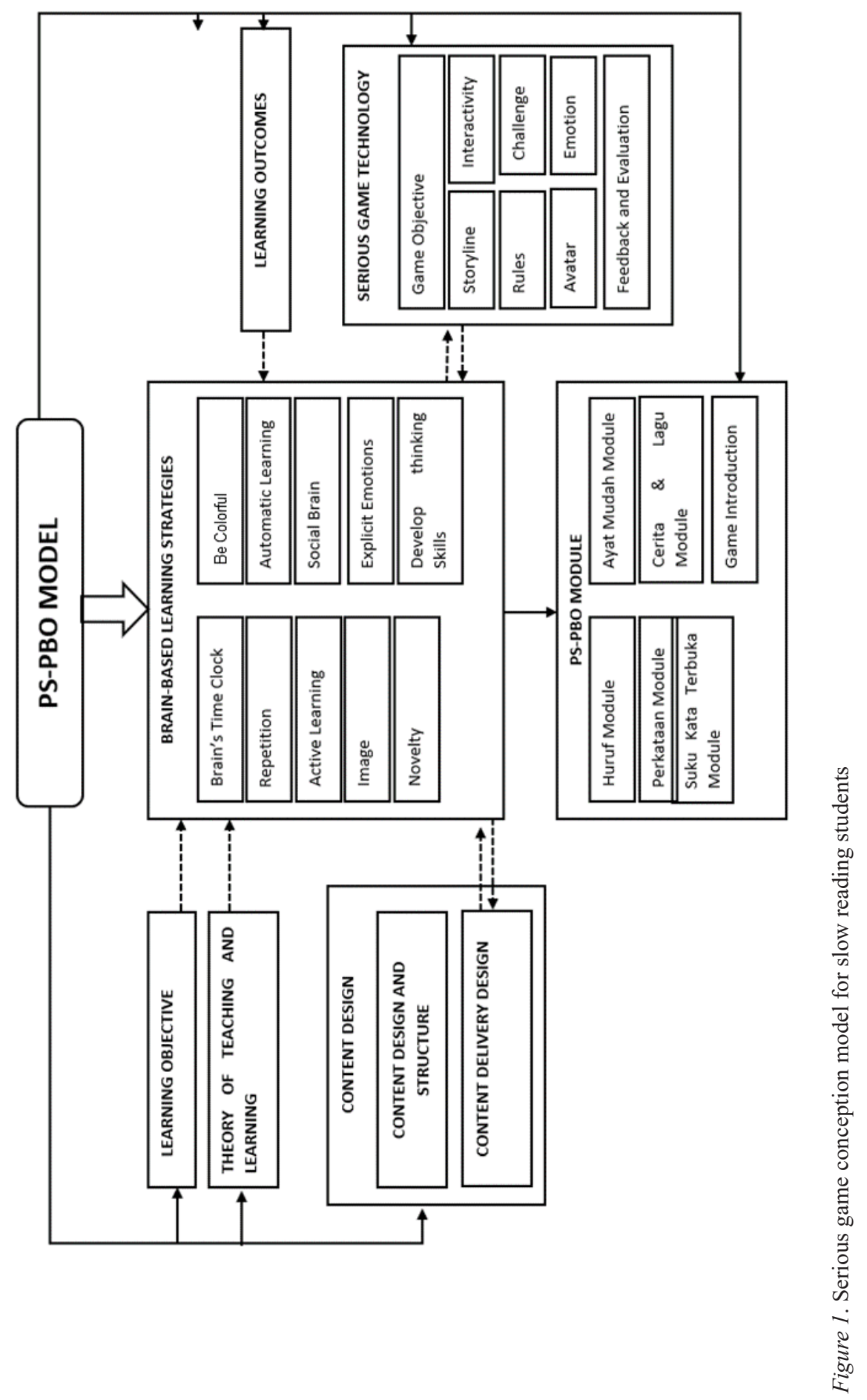


Table 4

Classification based on Bloom's Ordered Thinking Skills

\begin{tabular}{|c|c|c|c|}
\hline Learning Mechanics & Thinking Skills & Game Mechanics & Thinking Skills \\
\hline Learning Objective & Understanding & Storyline & Retention \\
\hline Learning Theory & Analyzing, Retention & Avatar & Retention \\
\hline $\begin{array}{l}\text { Content Design and } \\
\text { Structure }\end{array}$ & Understanding & Feedback & Analyzing \\
\hline $\begin{array}{l}\text { Content Delivery } \\
\text { Design }\end{array}$ & $\begin{array}{l}\text { Understanding, } \\
\text { Retention }\end{array}$ & Interactivity & Applying \\
\hline $\begin{array}{l}\text { Teaching aid used } \\
\text { (Technology) }\end{array}$ & Evaluation & Emotional & Retention \\
\hline \multirow[t]{3}{*}{ Strategy used } & Retention, Evaluation & Rules & Understanding \\
\hline & & Game Objective & Understanding \\
\hline & & Challenge & Retention \\
\hline
\end{tabular}

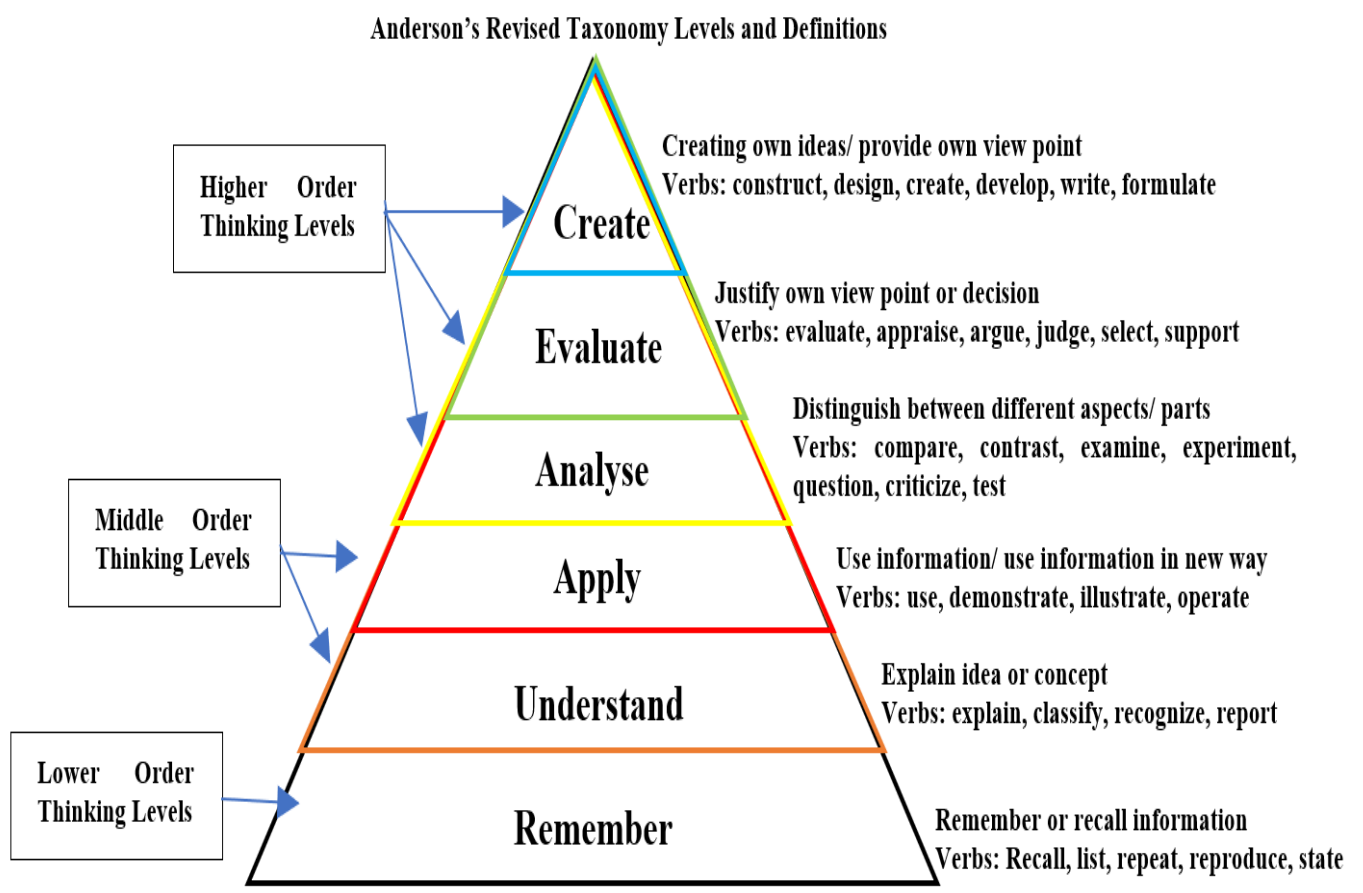

Figure 2. Anderson's Taxonomy and Level Descriptors; Adapted From (Sun, 2007) 


\section{Learning Components}

The game component can be divided into six main elements, i.e. learning objective, learning theory, content design and structure, content delivery design, teaching aid used (Technology) and strategy used.

Instructional Objective. Instructional Objective: An instructional purpose is a statement that describes what the learner will do after the lesson is completed. A success goal is a comprehensive summary of what students will be expected to achieve after completing an instruction unit. For example, in this study, after completing the application, students expect to increase their motivation and skills in literacy skills.

Instructional Theories. The instructional theory describes how to help people learn, develop and create conditions that boost learning and improve instruction. There are three basic types of learning theory: behaviorist, cognitive constructivist, and social constructivist. In this application, we applied those learning theories using specific strategies and techniques: brain-based learning. Teachers need to understand learning theories to be prepared to utilize them in their classrooms.

Content Design and Structure. Lesson content design includes learning content according to the learning curriculum and presented in planned modules. Since teachers had no specific modules in learning, the researcher conducted content validation with five LINUS and Rehabilitation teachers to validate the game content. The Primary Integrated Skills (KBSR) curriculum is used as a guideline in determining the teaching goals and content of the model.

Content Delivery Design. The selected learning content is divided into submodules, while the learning objectives are included in each activity module as prescribed during the analysis phase. The steps involved in content structure design are navigation maps, logic flow charts, and storyboards. The navigation map links the contents of the modules and provides an interactive logic flow of the interface. Storyboards allow designers to get an overview of the structure of the courseware.

Serious Game Technology and Instructional Media. Instructional media are part of the instructional plan. It is a tool (other than teachers, textbooks and printed materials) that delivers lessons to students. It aims to produce an exciting and meaningful teaching and learning process while helping to achieve learning goals.

Teaching and Learning Strategies. The prototype model was designed by applying a Brain-Based Learning strategy. This BBL strategy is applied by Hileman (2006) in a game model. 


\section{Serious Game Component}

The game component can be divided into six main elements, i.e. game objective, storyline, avatar, emotion, feedback, interactivity, rules, challenge.

Game Objective. A learning objective is the game's structure appropriate for the instructional objectives, for the audience's characteristics and intended use. As a result, it is essential to double-check that the games you plan to include align with your initial goals. For this application, the learning objective for the game is to increase the knowledge and skills in literacy for Halus students.

Storyline. The story is about the characters, of course. It is also about what the player sees. However, most importantly, it is about what the player does in the context of the narrative. To make the games have a good storyline, first; i) Outlines the major storyline, ii) Decide what type of game it will be, iii) Develop your world, iv) Create your main characters and v) Start writing the major story. This game is jungle and animal-themed, where players must help the animals that represent each module.

Avatar. Avatars in games are the player's representation in the game world. Users create avatars on various platforms to represent themselves when gaming, either serious or not serious. In this game, a bird represents the instructor to guide the users throughout the game.

Emotion. Game emotions are emotions generated due to winning, losing, accomplishment, and frustration. When you are playing a game, game emotions are directly related to your performance. Emotions are fundamental for players to engage with games deeply. Players' responses in a game are affected by their emotional states. If, in turn, it could affect the way the game responds, the player-game interaction could be augmented and enriched by magnitudes realizing affective loop-enabled games.

Interactivity. Interactivity is a dialogue between a computer and a user, and a user can interact with teaching materials. The game allows players to socialize either player with players or players with computers. Interactivity includes the speed of feedback or response to user activity, adaptability between humans and systems, instant feedback, and two-way communication between computer and human.

Rules. The effects of game mechanics are game rules, constraints in games that exist on each player's actions and abilities. Rules play an essential role in video games because they show how to win the game and how it works. In the game, there must be rules for increased learning. Clear instructions and methods for each game are essential. They are 
a guideline and rules for players to follow. Rules mean the guidelines that describe the relationship between the player and the environment (Narayanasamy et al., 2006).

Challenge. Challenging can avoid boredom. Boredom can be avoided by challenging yourself. A challenging game would typically entice more learners to participate, resulting in increased participation and keeping in mind that the challenge should be suitable for the student's ability level. Introducing a challenge that is not easy to bore students with and is not too challenging to solve will increase student motivation, so be careful!

Feedback and Evaluation. Meaningful feedback in a game is critical to know whether learning goals are achieved, encourage knowledge construction, and reflect on existing and complete learning activities. Students' mistakes can be corrected, and students do not continue to make mistakes. In this serious game, the researcher used corrective feedback that helps with learning and provides guidance. It is called corrective feedback because if the learner did the wrong thing, they would be prompted or guided toward a more appropriate action (Kapp 2012). This corrective feedback informs the learner that their action was wrong, provides knowledge of the correct response, and indicates the right answer.

\section{Brain-based Learning Component}

For effective learning, serious games need to combine strategies and opportunities in-game designs to make them attractive. Hileman (2006) stated that the biological and chemical forces controlling the human brain are connected with learning. The human brain parts are intertwined to carry multiple brain functions such as thoughts, memories, sexuality, emotions, breathing, and creativity. Words, names, equations, vocabulary and facts are things that the brain cannot remember. The strategy by Hileman (2006) is a strategy that can be applied in the serious game and used by teachers in planning teaching activities so that brain use is in a state of readiness to learn. This strategy involves ten strategies known as BRAIN BASED.

B: Brain's Time Clock. Memory, interest, cognitive, attention, visual perception, stimulation, performance, mood and behavior are influenced by the brain cycle of 90 to 110 cycles called the ultra-ray rhythm. Therefore, it is essential to diversify teaching and learning activities or training sessions of not more than 12 to 15 minutes for active learning, especially for children aged 9-12.

R: Repetition. Memory Repetition of information reinforces the connections into the brain. When the content is repeated in various ways, the brain stores information efficiently. However, teachers need to be careful about using this strategy. If used correctly, knowledge 
and skills can be used quickly and become more accurate because it is known. On the contrary, doing too much of the same thing causes the students to become bored.

A: Active Learning. This serious game requires students to be actively involved mentally and physically. When one learns through actions, they become more energetic and gain information more effectively. When the students are active, it can increase blood flow to the entire body and improve their memory. If the students sit for an extended period, it may cause low energy levels for them. An interactive game environment can add sensory stimulation to increase blood pressure and adrenaline levels to eliminate drowsiness, reduce anxiety, and strengthen information.

I: Images. Researches on the brain found that meaningful image concepts enable students to keep information in memory for the long term. In addition, visuals help students understand the content, attract attention and increase the students' percentage of remembrance. Hence, it is suggested that serious games need to be designed with text and graphics, diagrams, and videos.

N: Novelty. The level of dopamine increases in the brain as students know the stimulus that can reward them when they see something new. Therefore, it encourages students to look for rewards in whatever they do. For example, serious games apply a rewarding element to each level to stimulate the students' interest in playing.

B: Be Colorful. Color correlates with central nerves, and humans remember colors better than verbal or textual signals only. Colors also play a role in attracting attention, where black and white images can only draw one's attention for less than two seconds compared to colored images. Among the advantages of using the right colors in designs are; 1) Colors enhance software introduction up to $80 \%$; 2) Colors can be read more frequently by $42 \%$; 3) colors can increase the reader's interest by up to 40\%; 4) Colors can increase learning from $55 \%$ to $78 \%$; and 5 ) colors can increase understanding by $73 \%$. Therefore, color compositions are essential for increased interest.

A: Automatic Learning. Automatic learning is information that is obtained through the use of electronic and mechanical tools. Indirect learning happens when students play games. Non-verbal communication is important in serious games. Designers need to stimulate students to enjoy learning by creating a positive environment with adequate resources. The components of games can enable students to play and learn at the same time indirectly. 
S: Social Brain. Students have many opportunities to interact with teachers and other students through serious games, including students of different genders.

E: Elicit Emotions. Games can give players various emotions, ranging from frustration to excitement, from sad to anger and boredom to fun. Feelings are important for attention, perception, memory, and problem-solving. Acetylcholine in the synapse can be activated through the happy emotions generated from the game. Activating acetylcholine can help the received information be processed more quickly and memory stored better for the long term. By storytelling, students remember the stimulus more easily. Storytelling is one of the best ways to raise emotions like risk, happiness, insistence, and excitement. In addition, storytelling can help store information content.

D: Develop Thinking Skills. Problem-solving in serious games enables learning content to be related to the real world. Effective serious games allow students to collect information, generate results, and present the final decision. Before testing, students must follow the tutorials and training modules with an activity module that incorporates all the skills learned in this serious game.

\section{RESULTS AND DISCUSSION}

As the number of serious game users grows significantly and their social and educational impact is high, a review was conducted to analyze this topic's main aspects. As a result of this process, the game model was designed based on findings that suit a slow learner. Our research results indicate that games with Brain-based learning strategies apply in a serious game together with games and pedagogy elements. This model was created to suit students who are left out in learning, especially for slow-reading students. To produce students who master literacy skills, teaching aids and appropriate approaches to the 21 st-century generation need to be aligned with technology development. Innovation in education begins with conventional methods. Computer-assisted learning through digital games embraces multimedia elements, which is the choice of T\&L. Game emphasizes students to actively involved in the T\&L process conducted by teachers and is known as a student-centered learning approach.

This model focuses on a serious game base of education and games that uses learning and game mechanics to acquire reading skills and motivation in learning. Based on the SLR conduct, components of games and learning are acquired. The BBL strategy component is also applied to the conception model. Preliminary studies were conducted to strengthen the findings in SLR to form a robust conceptual model. This component selection is selected based on their thinking skills. This serious game aims to help Halus students master lowerorder thinking skills, including Remembering, Understanding, and Applying. Students 
are not able to move to higher-order thinking when they skip the lower-order thinking skills. This person will not be prepared for real-life situations. Therefore, this is because lower-order thinking skills only need to be recalled and slightly understood. The serious game model focuses on lower-order thinking skills because it focuses on Halus students, especially the basic order thinking, which retention is and understanding.

Finally, this literature review helped identify research gaps in features related to approaches or strategies, pedagogical and game aspects that influence the serious game's design. This study's finding is significant for developing good quality serious games because aspects have not yet been explored extensively, especially for the strategies or approaches that have been applied. Besides, this work for new research projects is considered a basis for developing a serious game that integrates the most powerful game features to enhance literacy skills and increase motivation, especially for slow learners.

Besides, the BBL approach or strategy is used in learning and game mechanics. Student exposure to brain-based teaching strategies has helped students focus on learning and achieving the highest learning level. The findings show that BBL elements have already been used in conventional teaching but are not explicitly emphasized. Using game component and strategy application B.R.A.I.N.B.A.S.E.D into a serious game model can optimize the brain's use during the T\&L process. Teaching strategies involving auditory, visual and kinesthetic provide the space for students to maximize their learning abilities to improve reading literacy skills and improve their learning motivation.

Education can significantly differ from school to school because of the lack of clear national policies related to digital gamers' engagement in game-based learning. As a result, the decision is left to school principals or individual teachers in many cases. Consequently, institutes focusing on game-based research must ensure a continuous two-way connection with teachers to integrate game-based learning into formal education.

For future work, the researcher will validate this conceptual model through the Delphi Technique. The Delphi technique is the best method to obtain expert consent in determining the elements included in the module's design. In addition, this technique will validate each element selected from the SLR Method and the preliminary study conducted.

\section{CONCLUSION}

In conclusion, this developed model is expected to guide developers in designing games compatible with Halus students. The game components and the strategies used are considered to have a good impact on Halus students.

\section{ACKNOWLEDGEMENT}

This study was funded by the Fundamental Research Grant Scheme FRGS/1/2019/ICT04/ UKM/02/1. This work by the Faculty of Information Science and Technology, Universiti 
Kebangsaan Malaysia, through the grant code FTM 1. The authors would like to thank the school principal of the two schools involved in this research, the LINUS and Pemulihan teachers, their valuable help, and the Faculty of Information Science and Technology, Universiti Kebangsaan Malaysia, for providing facilities and moral support.

\section{REFERENCES}

Abidin, S. R. Z., Noor, S. F. M., \& Ashaari, N. S. (2017). Guidelines of brain-based learning through serious game for slow reader students. In 2017 6th International Conference on Electrical Engineering and Informatics (ICEEI) (pp. 1-6). IEEE Publishing. https://doi.org/10.1109/ICEEI.2017.8312461

Abidin, S. R. Z., Noor, S. F. M., \& Ashaari, N. S. (2019). Low-fidelity prototype design for serious game for slow-reading students. International Journal of Advanced Computer Science and Application, 10(3), 270-276. https://doi.org/10.14569/IJACSA.2019.0100335

Ahmad, N. A., Hashim, M., Al-Juboori, A. A. Z. A., \& Zaidan, B. B. (2017). An effective diagnostic to overcome reading difficulties among learners with average reading ability. International Journal of Arts \& Sciences, 10(1), 299-303.

Ahmad, W. F. W., Noordin, S. M., \& Shariffuldin, N. S. M. (2013). Development of a multimedia courseware for slow learner children with reading difficulties: MyLINUS. In Advances in Visual Informatics, IVIC (pp. 371-382). Springer. https://doi.org/10.1007/978-3-319-02958-0_34

Anderson, L. W., \& Krathwohl, D. R. (2001). A taxonomy for learning, teaching, and assessing: A revision of bloom 's taxonomy of educational objectives (Allyn \& Ba). Pearson Education Group.

Auzar, A. (2012). Keberkesanan penggunaan perisian asas membaca [Effectiveness of using basic reading software]. GEMA OnlineTM Journal of Language Studies, 12(2), 629-644.

Azid, N., Yusoff, N., Rawian, R., Sabarudin, N., \& Ishak, M. Z. (2020). Evaluating user experience of using cerdik BM series 1 interactive pedagogical tool. International Journal of Instruction, 13(4), 409-426. https://doi.org/10.29333/iji.2020.13426a

Bandara, W., Miskon, S., \& Fielt, E. (2011). A systematic, tool-supported method for conducting literature reviews in information systems. In ECIS 2011 proceedings [19th European conference on information systems] (pp. 1-13). AIS Electronic Library (AISeL)/Association for Information Systems.

Bawaneh, A. K. A., Zain, A. N. M., \& Ghazali, M. (2010). The effectiveness of conflict maps and the V-shape teaching method in science conceptual change among eighth-grade students in Jordan. International Education Studies, 3(2), 96-108. https://doi.org/10.5539/ies.v3n1p96

Bawaneh, A., Nurulazam, A., \& Salmiza, S. (, 2012). The effect of a brain-based teaching method on conceptual change in students ' understanding of electricity change agent. International Journal of Physics \& Chemistry Education, 4(2), 79-96.

Bellotti, F., Berta, R., \& Gloria, A. D. (2010). Designing effective serious games: Opportunities and challenges for research. International Journal of Emerging Technologies in Learning (IJET), 5, 22-35. https://doi. org/10.3991/ijet.v5s3.1500 
Binulal, K. R., \& Aravind, A. (2013). Review of related literature on brain-based learning. Indian Journal of Applied Research, 3(7), 179-180.

Boyler, S. (2010). Teaching toolkit: An introduction to games based learning. UCD Teaching and Learning, 5(January), 254-257.

Caine, R. N., \& Caine, G. (1991). Making connections: Teaching and the human brain. Addison-Wesley.

Chauhan, S. (2011). Slow learners: Their psychology and educational programmes. International Journal of Multidisciplinary Research, 1(8), 279-289.

Domínguez, A., Saenz-de-navarrete, J., Fernández-sanz, L., \& Pagés, C. (2013). Gamifying learning experiences: Practical implications and outcomes. Computers \& Education, 63, 380-392. https://doi. org/10.1016/j.compedu.2012.12.020

Driscoll, L. (2011). Introduction to primary research: Observations, surveys, and interviews. In C. Lowe \& P. Zemliansky (Eds.), Writing spaces: Readings on writing (Vol. 2, pp. 153-174). Parlor Press LLC.

Fazil, F., \& Saleh, S. (2016). Keberkesanan pendekatan pengajaran berasaskan otak dalam meningkatkan kefahaman pelajar tingkatan empat terhadap pembelajaran konsep dan mekanisme fotosintesis [The effectiveness of brain -based teaching approach in improving form four students' understanding of learning the concepts and mechanisms of photosynthesis]. Asia Pacific Journal of Educators and Education, 31, 69-83. https://doi.org/10.21315/apjee2016.31.5

Hileman, S. (2006). Motivating students using brain-based teaching strategies. The Agricultural Education Magazine, 80(2), 1-28. https://doi.org/10.1088/1742-6596/1157/2/022059

Hirschmann, R. (2020). Share of online gamers in Malaysia in 2020, by age group. Retrieved August 26, 2021, from https://www.statista.com/statistics/1117575/malaysia-age-breakdown-of-online-gamers/

Jamian, A. R. (2011). Permasalahan kemahiran membaca dan menulis Bahasa Melayu murid-murid sekolah rendah di luar bandar [Problems reading and writing skills malay primary school students in rural areas]. Jurnal Pendidikan Bahasa Melayu, 1(1), 1-1.

Jensen, E. (2008). Brain-based learning: The new paradigm of teaching. Corwin Press.

Kapp, K. (2012). The gamification of learning and instruction: Game-based methods and strategies for training and education. Pfeiffer.

KPM. (2015). Annual report 2015: Malaysia education blueprint 2013-2015. Kementerian Pendidikan Malaysia. Retrieved August. 5, 2020, from https:/www.moe.gov.my/images/kpm/pemberitahuan/3Laporan\%20Tahunan\%202015\%20PPPM\%202013-2025\%20(BM).pdf

Mahidin, E. M. M., Umar, K., Ismail, S. S., Ismail, R., \& Yusoff, M. Z. M. (2011). Preliminary testing on interactive Bahasa Melayu reading courseware for dyslexic children. In 2nd International Conference on Education and Management Technology (Vol. 13, pp. 245-249). IACSIT Press.

Mandar, S. D. (2011). Peranan cognitive neuroscience dalam dunia Pendidikan [The role of cognitive neuroscience in the world of education]. Prosiding SNaPP: Sains, Teknologi, 2(1), 369-376.

Martin, M. W., \& Shen, Y. (2014). The effects of game design on learning outcomes. Computers in the Schools, 31(1-2), 23-42. https://doi.org/10.1080/07380569.2014.879684 
Masrop, N. A. M, Din, H. A. M., Ariffin, A. N. Z., Salleh, N. M. M., \& Ahmad, I. F. (2015, June 8-9). Kesan permainan digital dalam pendidikan [The effect of digital games in education]. In Proceeding of International Conference on Information Technology \& Society (pp. 1-7). Kuala Lumpur, Malaysia.

Miswan, M., \& Adnan, H. M. (2015). Pembangunan aplikasi peranti mudah alih untuk kemahiran membaca kanak-kanak: aplikasi literasi linus (LILIN) [Development of mobile device applications for children's reading skills: Linus literacy application (LILIN)]. Jurnal Pengajian Media Malaysia, 17(2), 64-78.

Møller, L., \& Hansen, P. K. (2016). Framing serious games development as a matter of business. International Journal of Serious Games, 3(1), 33-40.

Narayanasamy, V., Wong, K. W., Fung, C. C., \& Rai, S. (2006). Distinguishing games and simulation games from simulators. Computers in Entertainment, 4(2), 9-es. https://doi.org/10.1145/1129006.1129021

Ng, K. H., Bakri, A., \& Rahman, A. A. (2015). A review on courseware for down syndrome children. Journal of Information Systems Research and Innovation, 8, 56-65.

Ng, K. H., Bakri, A., \& Rahman, A. A. (2016). Effects of persuasive designed courseware on children with learning difficulties in learning Malay language subject. Education and Information Technologies, 21(5), 1413-1431. http://doi.org/10.1007/s10639-015-9391-7

Othman, Y., \& Pakar, D. R. (2011). Kesan aplikasi perisian cerita interaktif semasa mengajarkan kemahiran bacaan dan kefahaman dalam kalangan murid tahun 4 di Brunei Darussalam [The impact of interactive story software application in teaching reading and comprehension skills among year 4 students in Brunei Darussalam]. Jurnal Pendidikan Bahasa Melayu, 1(1), 27-49.

Peirce, N. (2013). Digital game-based learning for early childhood: A state of the art report. Learnovate Centre.

Ramli, R., \& Zaman, H. B. (2011). Designing usability evaluation methodology framework of augmented reality basic reading courseware (AR BACA SindD) for down syndrome learner. In Proceedings of the 2011 International Conference on Electrical Engineering and Informatics (pp. 1-5). IEEE Publishing. https://doi.org/10.1109/ICEEI.2011.6021807

Saleh, S., \& Halim, A. D. (2016). Kecenderungan otak dan hubungannya dengan pencapaian dan motivasi pelajar [Brain tendency and its relationship with student achievement and motivation]. Jurnal Pendidikan Malaysia, 41(1), 65-70.

Shapi'i, A., \& Ghulam, S. (2016). Model for educational game using natural user interface. International Journal of Computer Games Technology, 2016, 1-7. https://doi.org/10.1155/2016/6890351

She, H. (2012). Promoting students' learning of air pressure concepts: The interrelationship of teaching approaches and student learning characteristics. The Journal of Experimental Education, 7(1), 29-51.

Sidek, S. F., Fathil, N. S., Zain, N. Z. M., \& Muhammad, K. (2014). Pembangunan perisian kursus [Courseware development]. Jurnal Pendidikan Bahasa Melayu, 4(1), 1-10.

Stanberry, K., \& Raskind, M. H. (2019). Assistive technology for kids with learning disabilities: An overview. Retrieved February 20, 2021, from https:/www.readingrockets.org/article/assistive-technology-kidslearning-disabilities-overview

Su, T. Y., Gates, P., \& Harrison, I. (2016). Digital games and learning mathematics: Student, teacher and parent perspectives. International Journal of Serious Games, 3(4), 55-68. 
Sun, M. (2007). Using the organizational and narrative thread structures in an e-book to support comprehension (Doctoral dissertation). Robert Gordon University, UK.

Suratin, S. F., \& Mahadi, B. (2016). A review of learning courseware for children with learning disabilities in Malaysia. Journal of Information Systems Research and Innovation, 10(December), 1-8.

Yussof, R. L., \& Shima, T. P. T. N. (2012). Reading activities using the scaffolding in MEL-SindD for down syndrome children. Procedia-Social and Behavioral Sciences, 35, 121-128. https://doi.org/10.1016/j. sbspro.2012.02.070

Zaki, N. A. A., Wook, T. S. M. T., \& Ahmad, K. (2015, August). Analysis and classification of serious games for cognitive stimulation. In 2015 International Conference on Electrical Engineering and Informatics (ICEEI) (pp. 612-617). IEEE Publishing. https://doi.org/10.1109/ICEEI.2015.7352572

Zhonggen, Y. (2019). A meta-analysis of use of serious games in education over a decade. International Journal of Computer Games Technology, 2019, Article 4797032. https://doi.org/10.1155/2019/4797032 
